\title{
The Troubled Pasts of Hungarian and German Minorities in Slovakia and Their Representation in Museums
}

\author{
Tereza Juhászová
}

\section{Charles University}

\begin{abstract}
In the 20th century, the two world wars reshaped the map of Central Europe as well as the status of Central Europe's diverse societies. In my article, I focus on the Hungarian and German minorities in Slovakia and the representation of their problematic historical past in contemporary Slovak museums. More specifically, I zoom in on the exhibition Exchanged Homes displayed in Bratislava, which aims to commemorate the fate of Hungarians, Germans, and Slovaks, all of whom were affected by the population transfers after World War II. Based on the concept of memorial museums theorized by Paul Williams, I aim to show how the different exhibitions engage with the traumatic past of forceful resettlement. By offering multifaceted memories of a troubled past, these exhibitions avoid categorizing "victims" and "perpetrators" along national or ethnic lines. My paper thus analyzes the concepts and components of the exhibitions - the context of the postwar events, oral history interviews, and objects of everyday use that should bring the visitor closer to the experience of the people who were forced to leave. I argue that exhibitions of this sort have the ability to challenge the dominant historical narrative focusing on a national "Slovak" history and help the process of reconciliation between the Slovak majority society, and the Hungarian and German minorities.
\end{abstract}

\section{Keywords}

Slovakia; Hungarian minority; German minority; museum; forced resettlement What is forgotten need not necessarily be lost forever.

Aleida Assmann

\section{Introduction}

Central Europe and its diverse societies faced significant border changes and political regime shifts during the 20th century. Ethnically, nationally,

\footnotetext{
* Tereza Juhászová, Institute of International Studies, Faculty of Social Sciences, Charles University, U Kř́iže 8, 15800 Prague, Czech Republic; tereza.auzka@fsv.cuni.cz.

This study was financially supported by the Charles University Grant Agency (GA UK), grant no. 800217. The idea of this paper was developed through the Primus Research Project under the grant "Beyond Hegemonic Narratives and Myths: Troubled Pasts in the History and Memory of East-Central \& South-East Europe," PRIMUS/HUM/12 - 960949. I would also like to thank János Hushegyi and Martin Piaček, who participated in the establishment of the exhibition Exchanged Homes.
} 
or religiously defined groups of people found themselves fluctuating between favored and disadvantaged social positions, at times identifying with the majority and at other times identifying as minority. The cases of German and Hungarian populations in the territory of today's Slovakia were no exception. After the end of World War II, both were labeled by the Czechoslovak Republic as collectively guilty for the destruction of the joint state as well as wartime suffering, and thus subjected to forced resettlements. ${ }^{1}$ Discussions about these events fell dormant under the communist regime, and the situation changed only slowly in the 1980s. Academics fully opened the topic in the years after the revolution, but the problematic past of minorities in Slovakia still remained a sensitive question in the public sphere. This paper deals with the contemporary representations of the controversial Slovak past in cultural institutions, such as museums and art galleries, with an emphasis on issues connected with the Hungarian and German minorities.

The main focus lies on the analysis of museums, which are generally understood as public sites of culture, whose aim is primarily to support the idea of the nationstate and the construction of national identity (Rivera-Orraca 2009, 32; Autry 2013, 58). State museums, and especially state museums of history, present the official national discourse of the past and, through diverse remembrance practices such as the commemorations of particular events, reinforce the legitimacy of a state (Simon 2012, 93). In this paper, I address the official Slovak institutions of remembrance in an effort to show how the official narrative of Slovak history presented in cultural institutions changed in the years after the fall of the communist regime; I also concentrate on the extent to which these institutions deal with the controversial issues of the Slovak past. In brief, I focus on the exhibition Exchanged Homes (Vymenené domovy) (Figures 1-3), which aims to commemorate the fates of Hungarians, Germans, and Slovaks affected by the population transfers. The exhibition explicitly states that its goal is to "build a memorial of this period". Therefore, the theoretical part of this paper relies on the concept of memorial museum put forth by Paul Williams, who defined memorial museums as having a mission "to illuminate, commemorate, and educate about a particular, bounded, and vivid historical event" (Williams 2008, 24). Guided by Williams's theoretical considerations (Williams 2008, 100), this paper argues that a memorial museum —in this case, the "memorial exhibition" Exchanged Homes - can help the process of reconciliation and cooperation in contemporary Slovak society because it presents the postwar

1 According to the concept of collective guilt, members of certain collectivities or parts of society are responsible for particular actions; in the case of Czechoslovakia the German and Hungarian minorities were blamed for the outbreak of World War II and the disintegration of the Czechoslovak state. (See Gabzdilová-Olejníková and Olejník 2004; Vadkerty et al. 2002). 
period in an alternative way, showing the past from a heterogeneous point of view held by different participants to the events.

Fig. 1 Invitation for the exhibition opening. (Source: https:/lallevents.in/bratislavalvymenen\%C3\%A9-domovy-felcser\%C3\%A9lt-otthonok-austausch-der-heimat/1680353312256394, Accessed 14 June 2017).
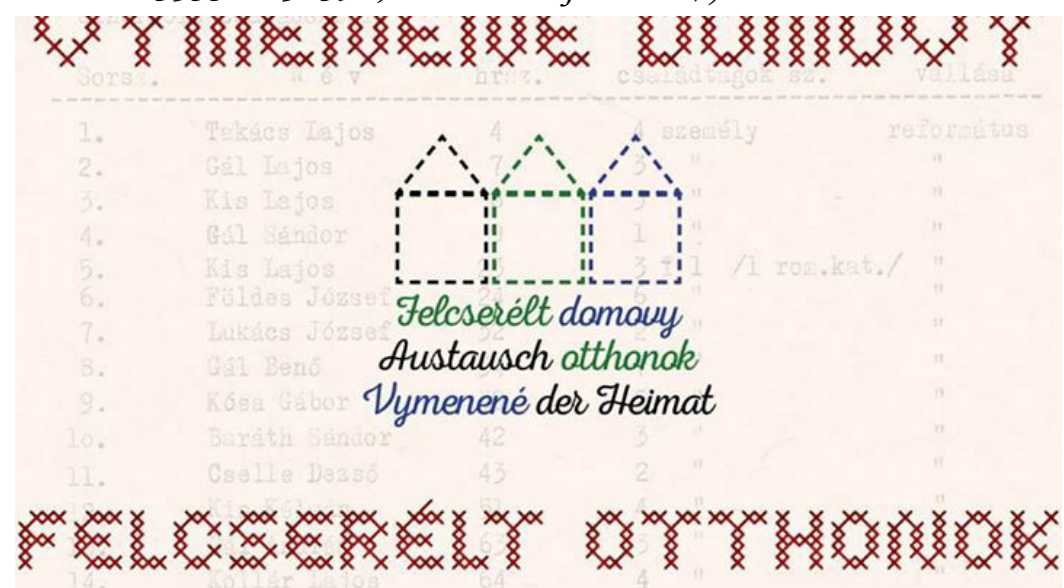

SzNM - A Szlovákiai Magyar Kultúra Múzeuma és a Hagyományok és Értékek Polgári Társulás SNM - Múzeum kultúry Mađarov na Slovensku a Občianske združenie Tradície a hodnoty

tisztelettel meghívják Önt a

Felcserélt otthonok c. kiállítás megnyitójára, melyre 2016. november 30-án 17. 00 órakor kerül sor

a Brämer-kúria földszinti kiállítótermében.

Vás srdečne pozývajú na otvorenie výstavy Vymenené domovy ktoré sa uskutoční dňa 30. novembra 2016 o 17. 00 hod. vo výstavných priestoroch Brämerovej kúrie.

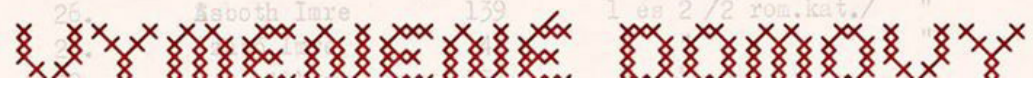

This paper addresses the following question: To what extent do contemporary Slovak museums and galleries provide any reflection on the problematic and traumatic 20th century, including the story of the Hungarian and German minorities? Firstly, the Slovak museums and the recent development of their exhibitions are analyzed to get an overview of the Slovak context, with a brief insight into the regional context as well. The following section focuses on the central issue-the troubled pasts of the Hungarian and German minorities as presented in museums. 
Tereza Juhászová, The Troubled Pasts of Hungarian and German Minorities in Slovakia and Their Representation in Museums

Fig. 2 Exhibition titled "Exchanged Homes" (Photo: Tereza Auzká).

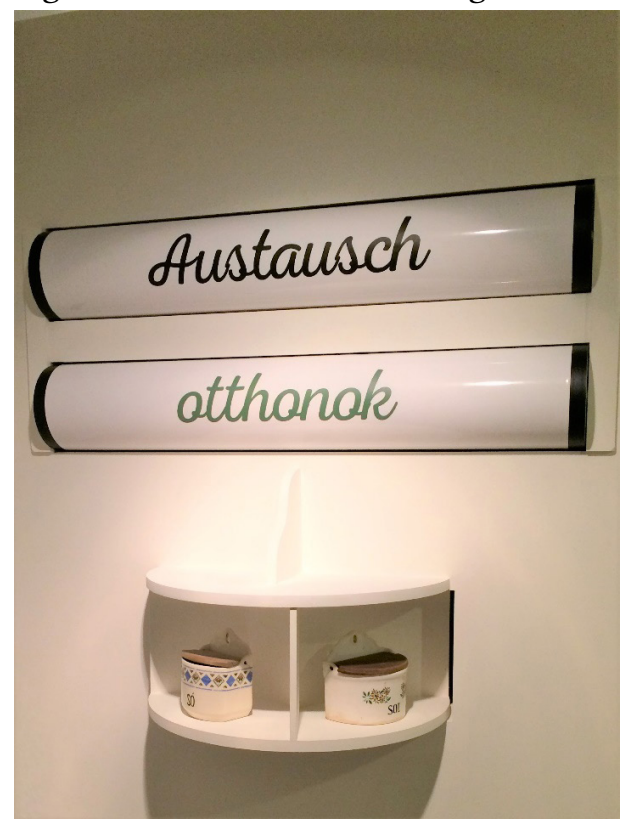

Fig. 3 Exhibition titled "Exchanged Homes" (Photo: Tereza Auzká).

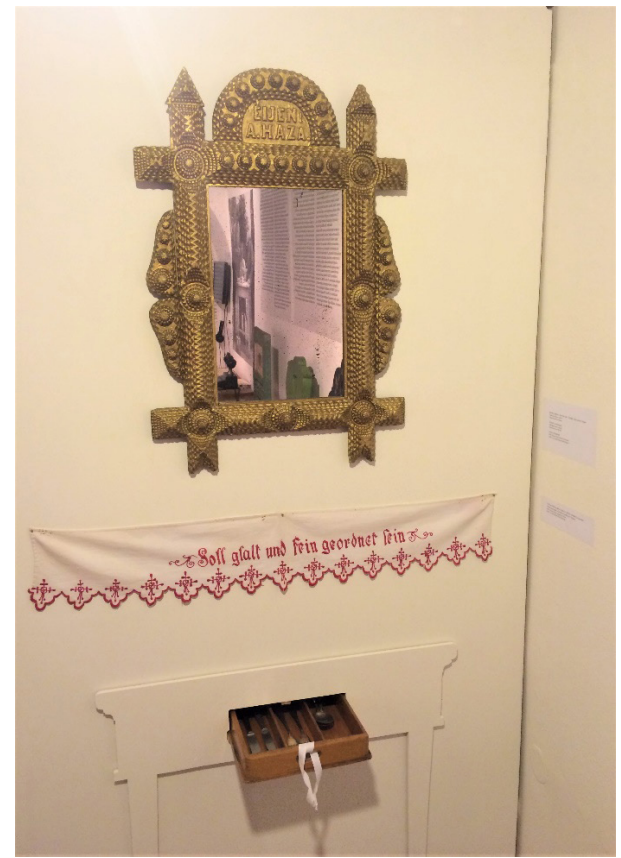


This study is based on field research in Bratislava in February and June 2017, as part of which I visited the museums and exhibitions related to the examined topic, namely, the specialized museums of the Slovak National Museum (SNM) - the Museum of Hungarian Culture in Slovakia, the Museum of Carpathian German Culture, and the Museum of History-and the Slovak National Gallery. During the visits, I conducted interviews with museum employees and the curators of the exhibition Exchanged Homes. ${ }^{2}$ The argument of this paper is also supported by the secondary literature on Slovak museums (Hudek 2011; Maráky 2015, 2017), the official web pages of the museums and galleries, as well as online articles commenting on the exhibitions.

\section{Historical Museums as Places of Memory}

When talking about museums of history, we have to concentrate on what they exhibit. What is their aim? Whose "history" are they presenting? The reputable French historian Pierre Nora understood museums as one of the elementary tools of history, perceived by him as problematic reconstructions of the past (Nora 1989, 12). Museums, according to Nora, are lieux de mémoire (places of memory), "the ultimate embodiments of a memorial consciousness that has barely survived in a historical age that calls out for memory because it has abandoned it" (Nora 1989, 12). Cultural and social memory is in permanent evolution in developing individuals as well as among groups and, therefore, differs from history, which is static and universal (Nora 1989, 8). Nora focused on national history, whose aim is to reinforce the nation-state and solidify its legitimacy. In this framework, museums should serve as the bastions of national history and transmit the official version of the past to the people, whose personal memories became irrelevant in comparison with the "grand narrative". The monolithic narrative about a "common past" has the power to construct a group's identity based on the perception of shared events that the people "went through together". After these considerations, Nora turned to the question of minorities, whose historical narrative differs from the predominant one. In order to keep the past experience of the minority

2 The leader of the project Exchanged Homes was the director of the Museum of Hungarian Culture in Slovakia, Gabriella Jarábik. After an e-mail conversation with Gabriella Jarábik, the author was suggested to interview János Hushegyi, who is one of the curators of the Museum of Hungarian Culture in Slovakia and responsible for the digitalized part of the exhibition. The author also had an e-mail conversation with Martin Piaček (Department of Sculpture, Object, Installation; Academy of Fine Arts and Design in Bratislava), responsible for the technical arrangement of the exhibition together with Peter Baumann. The exhibition scenario was created by Sylvia Sipos (Museum of Hungarian Culture in Slovakia) and by artist Réka Szabó, who also designed the exhibition. The factual part of the exhibition was consulted with historian Árpád Popély (Forum Minority Research Institute). 
alive or to revive it, minority groups also create their own lieux de mémorie. To put it in Nora's words, "[...] If what they defended were not threatened, there would be no need to build them" (Nora 1989, 12).

This bring us to the motto of this paper- "what is forgotten need not necessarily be lost forever" - a quotation from Aleida Assmann $(2011,337)$. She coined the terms "active and passive remembering", stating that some parts of memory are intentionally highlighted, whereas others fade into obscurity. From this point of view, exhibitions in museums are "institutions of active memory", which help construct and reinforce the identities of particular groups (Assmann 2011, 335-337). The aforementioned quotation by Assmann pinpoints the disappearance and resurrection of certain pasts and memories, which we address in the Slovak context. Before approaching the displays of memory of Slovak national minorities in the museums of their culture and history, it is important to turn one's attention to cases of museums that have also became places of commemoration-memorial museums.

These museums emerged in the second half of the 20th century as new cultural institutions aimed at presenting traumatic pasts in an original way by combining official historical narratives and individual memories. The first comprehensive study of memorial museums was written by the museologist Paul Williams, who-in his book Memorial Museums: The Global Rush to Commemorate Atrocities - analyzed more than 20 memorial museums from all over the world (Williams 2008). He defined a memorial museum as a "specific kind of museum dedicated to a historical event commemorating mass suffering of some kind" (Williams 2008, 8). Williams focused not only on the informational content of memorial museums but also on the material part. According to Williams, exhibited objects that are connected with particular historical, and often traumatic, experiences attract visitors and bring their attention to people who lived through the presented events (Williams 2008, 6). The objects are not on display per se but because of the feelings that they evoke in the visitors. Here, Williams sees the problematic point, namely, the extended meaning of objects, which shall symbolize a certain part of the past and contribute to the establishment of historical myths (Williams 2008, 30). On the other hand, displaying objects, even with the primary intention to arouse emotional reactions, can be beneficial-especially with exhibitions that deal with shared traumatic pasts and are aimed at the reconciliation of various participating actors, as is shown in the example of the Exchanged Homes (Vymenené domovy) (Figures 1-3) exhibition in Bratislava. 


\section{Historical Museums in Slovakia and the Regional Context}

Before elaborating on the concrete exhibition, it is important to place the examined topic in the broader context of Slovak historical museums. The two most well-known museums of Slovak history are the SNM and the Museum of the Slovak National Uprising. Both of them are state museums established during the period of communism and presenting the official state narrative of history. This has significantly changed since the fall of communism and especially after the dissolution of Czechoslovakia in 1993. The museums did not have to follow the narrative of the communist ideology anymore, but they did have to struggle with a growing Slovak nationalism under the government of Vladimír Mečiar ${ }^{3}$ (Hudek 2011, 839). During the 1990s, both museumsespecially the SNM-tried oppose state nationalist politics of history. ${ }^{4}$ In this paper, I focus on two minority museums (the Museum of Hungarian Culture in Slovakia and the Museum of Carpathian German Culture), which were established within the Museum of History (part of the SNM) in the 1990s and, later on, became their own independent parts, which specialized in the representation of the history of the minorities in these museums ("Historické Múzeum: História Múzea," 2009). Since the Museum of Slovak National Uprising has always been keener to present the Slovak national narrative (Hudek 2011, 842), this paper does not deal with its exhibitions.

In his analysis of national museums in Slovakia, Adam Hudek emphasizes the attempts of the SNM during the 2000s to focus on contemporary history and leave out nationalist narratives, such as those justifying the ancient origin of the Slovak nation (Hudek 2011, 839). Hudek mentions two important and highly frequented exhibitions from 2002 and 2008- the Centre of Europe around the Year 1000 (Stred Európy okolo roku 1000) and How We Lived? Slovakia in the 20th Century (Ako sme žili? Slovensko v 20. storočí). The significance of the first exhibition lay mainly in the cooperation of historians and archaeologists from Central European countries (Germany, Czech Republic, Poland, Slovakia, and Hungary) and in the presentation of the common past of the region without stressing national narratives (Hudek 2011, 839; Blažej 2002). The other exhibition-How We Lived? - was organized on the occasion of the 15th anniversary of the Slovak Republic and concentrated on everyday life during the 20th century. It was very popular among the visitors (Hudek 2011,

3 Vladimír Mečiar (People’s Party - Movement for a Democratic Slovakia, Ludová strana - Hnutie za demokratické Slovensko, LS-HZDS) became the first prime minister of Slovakia after the dissolution of Czechoslovakia in 1993. The authoritarian character of Mečiar's government resulted in international isolation of Slovakia during the 1990s.

4 As Slovak historian Adam Hudek states, the Museum of Slovak National Uprising was always more subjected to the official state narrative of history (Hudek 2011, 842). 
839; "Ako sme žili? Slovensko v 20. Storočí," 2008). During this decade, SNM also cooperated on various projects dealing with controversial topics, such as the exhibition Slovak Myth (Slovensky mytus) in the Slovak National Gallery, which showed the manifestation of national myths in Slovak art ("Slovak $M y t h$ ", n.d.). In the past few years, however, the Museum of History of the SNM has avoided dealing with any controversial events of the 20th century.

In 2014, there was an exhibition entitled World War I: The Tragedy That Hit Everyone (Prvá svetová vojna. Tragédia, ktorá postihla všstkých), which commemorated the 100th anniversary of the beginning of the war; however, it unfortunately did not offer any original interpretations of the events (Kacsinecz 2014). Currently, the Museum of History offers the exhibition History of Slovakia (Dejiny Slovenska) in its newly renovated building (Bratislava Castle). This exhibition deals with the history of Slovakia but, interestingly, only up to the collapse of the Great Moravia at the beginning of the 10th century. The space of the exhibition is divided into two sections. The entrance hall presents the whole Slovak history in points written on columns in the middle of the room (e.g., on the "World War II" column, there are nine words summing up the period, such as "the Slovak State", "War outbreak", "Holocaust", and "Slovak National Uprising"). The second room is devoted to the archaeological findings through informational boards that are hung on the wall. On one of the boards, named The Nitra Princedom (Nitrianske kniežatstvo), it is written, “[...] One could see, just in this period and in similar supra-tribal units, the roots of the later Slovak nationality." This narrative stays in complete opposition to what the aims of the SNM were a decade ago. The former director of the SNM, Peter Maráky, in 2008 said, "It does not matter if you like it or not, the Slovaks have formed a nation predominantly in the 20th century, especially during the time of the so-called real socialism. Therefore, looking for old and even older Slovaks has no sense" (Maráky 2008; Hudek 2011, 839).

In recent years, the traumatic and controversial pasts of Slovak history have been mainly topics of either smaller exhibitions of the SNM (e.g., the Exchanged Homes: Figures 1-3) or exhibitions of other institutions such as the Slovak National Gallery. Very popular-according to the curators (Koklesová 2017)—was the exhibition Dream $\times$ Reality: Art \& Propaganda 1939-1945 (Sen $\times$ skutočnost. Umenie \& propaganda 1939-1945) in the Slovak National Gallery, which presented some art and propaganda during the years of the Slovak State (“Dream × Reality | Art \& Propaganda 1939-1945", n.d.).

5 The Nitra Princedom (Nitrianske Kniežatstvo), Information Board at the Exhibition History of Slovakia (Dejiny Slovenska), Museum of History of the SNM, visited on June 8, 2017. 
Similar to the exhibition Slovak Myth, even in this case, the curators went deeply into the controversial moments of Slovak history and nation building. These aforementioned exhibitions of the Slovak National Gallery reveal that instead of the SNM (and especially its branch-Museum of History), it is the Slovak National Gallery that repeatedly engages with controversial events of the Slovak history. Some of the exhibitions even raise heated debates in the society and among scholars as well. This was, for instance, the case of the exhibition Interrupted Song: The Art Of Socialist Realism 1948-1956 (Prerušená pieseñ: Umenie socialistického realizmu 1948-1956), presented in the main building of the Slovak National Gallery in 2012. The exhibition was even in the center of interest of the experts Grigorij Mesežnikov (2012) and Ol'ga Gyárfášová (2012) of the well-known Slovak think tank, Institute for Public Affairs (IVO), who criticized the lack of critical stance toward the presented pieces of art. On the other hand, the curator of the exhibition Alexandra Kusá reacted to the critique as follows: "Moral condemnations are not part of art historical research" (Kusá 2012, 5). In her defense of the exhibition, Kusá also pointed out that the exhibition not just presented the relevant pieces of art but also worked with archival documents (Kusá 2012, 5), which again shows the historical orientation of the Slovak National Gallery and its will to deal with historical topics that may turn into very controversial ones. Yet, some topics remain unaddressed on a nationwide scale, above all, the question of forced resettlements in postwar Czechoslovakia after 1945.

Generally, the topic of "national history" during World War II, as well as its immediate consequences, is very carefully dealt with in Central Europe. Especially sensitive until today is the question of "perpetrators" and "victims" of the war and postwar crimes. Interesting insight into the Central European perceptions of "perpetrators" and "victims"- usually categorized along ethnic lines-provide not just historical museums, but also Holocaust museums. In recent years, the attention of scholars has been focused, for instance, on two significantly different museums in Budapest, Hungary-the House of Terror Museum and the Holocaust Memorial and Documentation Center. These two cases are worth mentioning because they represent cases of completely distinct views on World War II and the issue of "perpetrators" and "victims". On the one hand, the House of Terror Museum emphasizes the victimhood of Hungarian people and the foreign origin of the perpetrators (Manchin 2015, 237); on the other hand, the Holocaust Memorial and Documentation Center-inspired by the U.S. Holocaust Memorial Museum-also discusses the Hungarian responsibility for the Holocaust (Radonić 2014, 1). However, acknowledgment of the involvement of the Central Europeans in the 
in Slovakia and Their Representation in Museums

Holocaust is still a rather careful manifestation in the Holocaust exhibitions. Even though new exhibitions about Holocaust emerge, they sometimes continue to present Central European nations as victims, or even rescuers of the Jews, as is, e.g., the case of the Ulma Family Museum of Poles Saving Jews in World War II in Markowa, Poland. In his article about this museum, historian Florian Peters praised the bottom-up approach of the exhibition but also criticized the present heroization of the Polish nation (Peters 2016). ${ }^{6}$ Therefore, acknowledgment of the involvement of Poles, Czechs, Slovaks, or Hungarians-who generally or in special cases present themselves as victims of Nazi Germany-in Holocaust is still problematic, as is the issue of the war and postwar crimes, in our case, especially the question of postwar resettlements. On the other hand, challenging exhibitions and international cooperation on this topic are also repeatedly presented in the public spacesuch as, in the Czech case, artistic interpretations of the postwar events by Lukás Houdek ${ }^{7}$ and Mark Ther ${ }^{8}$ or the work of the Czech and Slovak Citizens associations Antikomplex and Antikomplex.sk, which also cooperate with German and Austrian partners.

After this short introduction about the Slovak, and generally Central European, context of public representations of the traumatic past, this article concentrates on the contemporary exhibition Exchanged Homes (Vymenené domovy), which is a result of the work of the curators from the SNM-the Museum of Hungarian Culture in Slovakia, in cooperation with other Slovak and Hungarian institutions.

\section{The Troubled Pasts of Hungarian and German Minorities as Presented in Slovak Museums}

As mentioned, after 1945, Germans and Hungarians living in Czechoslovakia were found collectively guilty for World War II and, through decrees of the Czechoslovakian president Edvard Beneš, deprived of their citizenship

6 Florian Peters' article was published in the online journal Cultures of History Forum of the Imre Kertész Kolleg. This online journal provides a wide range of articles dealing with public representations of the past in Central, Eastern and Southeastern Europe.

7 Lukáš Houdek in his projects (The Art of Killing, 2012; The Art of Settling, 2011-2013; Abandoned Lives, 2009-2012) focused on the postwar fates of the Czech Germans. See more at: https://www. houdeklukas.com/.

8 Mark Ther dealt with the fates of Czech Germans in several projects such as in the short film Pflaumen (see: https://www.youtube.com/watch?v=FPwdzOeInEw) or in the exhibition Our Germans (naši Némci; see: http://artycok.tv/4238/our-germans). See more at: http://markther.com/\#.

9 The Czech Citizens associations Antikomplex, for instance, cooperated with the Austrian Center for Migration Research (Zentrum für Migrationsforschung) on the 2014-2015 Prague exhibition of the Austrian project Slowly It Has Become Better (Langsam ist es besser geworden, Pomalu začalo být zase dobre.) about the Czech and Moravian Germans who were expelled to Austria after World War II. 
status and property. The question of unwanted minorities should have been resolved by the forced resettlements that followed shortly after the war had ended. The resettlements were carried out under various circumstances. The expulsion of Germans from Czechoslovakia began violently right after the war without any agreement with the Allied powers until the Potsdam conference in July and August 1945. In the final protocol of the conference, the governments of the USA, the Soviet Union, and Great Britain stated that "the transfer to Germany of German populations [...] remaining in Poland, Czechoslovakia and Hungary will have to be undertaken" (The Berlin [Potsdam] Conference, 1945). The Beneš decree from August 2, 1945, followed up with the proclamation that the Czechoslovak citizens of German or Hungarian nationality were to lose their Czechoslovak citizenship (with exceptions) and therefore served as a basis for the official expulsion of the Germans (Gabzdilová-Olejníková and Olejník 2004, 94).

However, the Allied powers did not agree with the expulsion of the Hungarian minority, nor did the Hungarian government accept the Czechoslovak proposals of population exchanges or even an expulsion of Hungarians to Hungary. In order to persuade the Hungarian government to sign a bilateral agreement on the population exchange, the resettlement of Hungarians from southern Slovakia to Bohemia began. The Hungarian part, consequently, agreed with the treaty in the beginning of 1946, which was clearly disadvantageous for the Hungarian minority (Popély 2009, 51-52). During the exchange, Slovaks from Hungary could have moved to Czechoslovakia voluntarily, whereas Hungarians were resettled from Czechoslovakia by force. These violent postwar events significantly decreased the number of Hungarians, and especially Germans, in Czechoslovakia and considerably affected those who remained. Under communist rule, the hegemonic narrative emphasized that the members of the German minority were betrayers. The attitude of the Communist Party of Czechoslovakia toward the Hungarian minority was more complicated. After the communist takeover in 1948, the situation of the Hungarian minority slowly_and after huge discussion among the members of the Communist Party-improved. The citizenship, as well as certain part of previously owned land, was returned to the Hungarian minority and its members expelled to Bohemia were allowed to come back (Barnovský 2004, 182). Nevertheless, the topic of forced resettlements became a taboo, and the memories of witnesses were subjected to a state-imposed forgetting (Esbenshade 1995, 76).

The distorted official narrative of the postwar events dominated the public sphere, even though the first academic works opening the question of postwar population transfers appeared in the beginning of the 1980s (Bobák 1982). 
The democratization of Slovak society after 1989 enabled a more detailed focus on this topic. The situation of the Hungarian minority after World War II was analyzed in the Slovak context mainly by Katalin Vadkerty (Vadkerty et al. 2002), Zlatica Sáposová and Štefan Šutaj (Sáposová and Šutaj 2010; Šutaj 2012), and Árpád Popély (Popély 2009), while Soňa GabzdilováOlejníková and Milan Olejník (Gabzdilová-Olejníková and Olejník 2004) and Gabzdilová-Olejníková et al. (2005) wrote extensively on the German minority in the postwar period. The traumatic pasts of the Hungarian and German minorities are therefore thoroughly discussed in the Slovak Academy but remain a very sensitive topic in the public sphere. Especially, the issue of population exchange between Czechoslovakia and Hungary repeatedly appears in the political debates both in Hungary and Slovakia, raising heated debates about the postwar events. ${ }^{10}$ However, reflections of the postwar resettlements in museums and art galleries are rather scarce, and that is why I am focusing on the exhibition Exchanged Homes (Figures 1-3), which publicly introduced an original narrative of this issue.

The current exhibition (2016-2018), "Vymenené domovy-Felcserélt otthonokAustausch der Heimat" (meaning Exchanged Homes in the Slovak, Hungarian, and German languages), is located in the specialized museum of the SNM-the Museum of Hungarian Culture in Slovakia. The explicit aim of the exhibition, as written on the official websites and in the exhibition leaflet, is to "build a memorial" to the period of forced resettlements after World War II and present everyday life and the personal experiences of the people who were "victims of these events" ("Vymenené Domovy - Felcserélt Otthonok" n.d.). The curators, however, did not want to focus on the victimhood aspect of concrete parts of society; instead, they aimed to show various individual stories and perspectives symbolized by the usage of the Slovak, Hungarian, and partly German languages in the exhibition space. As Sylvia Siposová, one of the authors of the exhibition, states in a metaphoric way, "The key to the Exchanged Homes is exactly the diversity of its voices" (Siposová 2017, 63). Even though the exhibition presents the fates of three nationalities, the curators avoided presenting any "victims" and "perpetrators" of the war and postwar events along national lines. The curators decided to connect the fates of people of diverse nationalities and "break barriers between them" (Hushegyi 2017). Thus, the exhibition does not make any explicit point about perpetrators and, only cautiously mentions "strategies of the Czechoslovak government" or "decisions of the Allied Powers" in the descriptions provided on walls.

10 After the decision of the Hungarian Parliament in December 2012, April 12 (as the date in 1947 when the resettlement of Slovak Hungarians to Hungary, but also the other way around, began) is the Commemorative day of Hungarians expelled from Slovakia. 
The topic of passive bystanders or active participants in the persecution is not included, except for the possibility to look into a couple of exhibited archival documents, which usually contain names of higher-ranked officers who were in charge of resettlements or information about the institutions that spread official propaganda (such as the Slovak League). The focus on the various fates of mainly the victims of population transfers is understandable because of the lasting sensitivity of the topic and the fact that the perpetrators and victims (who could have remained in Czechoslovakia) may still live in one place without any desire to arouse old animosities. According to Williams, this strategy to exclude the issue of perpetrators is typical for the museums dealing with local and civic conflicts, where "both survivors and perpetrators often disappear back into everyday society" (Williams 2008, 133), as is exactly the case of Exchanged Homes. The curators obviously proceeded with caution so as to not break the possibly fragile cohabitation of the survivors and perpetrators. This was made apparent from the interview with one of the curators (Hushegyi 2017), as well as from the informational leaflet about the exhibition stating that "the tragic events and personal tragedies of these people have resulted in a long period of implacable disagreements between residents who forcedly found themselves in the same place".

Therefore, visitors entering the exhibition are at first only briefly informed about the topic of the exhibition-how did political decisions (the expulsion of Germans, the deportation of Hungarians to Bohemia, the repatriation of Slovaks and Czechs from abroad, the population exchange between Czechoslovakia and Hungary) affect the lives of individuals and "ethnic groups", and how the people of diverse nationalities were able to live together in the same place. The visitor is provided with a chronological list of postwar developments as well as more detailed descriptions of the events written on the walls in the Slovak and Hungarian languages without blaming any "ethnic" or social group. The usage of both languages serves as a "bridge" between the witnesses of the events of both nationalities, as well as between Slovak and Hungarian (or bilingual) visitors. A small shortcoming is that even though the exhibition targets the fates of Germans as well, thorough inscriptions in German are missing. The curators explain this omission by limited space (Hushegyi 2017), but I would argue that at least printed material in German would be sufficient. ${ }^{11}$

\footnotetext{
11 Here, it has to be stated that there is a brief information leaflet about the exhibition in Slovak, Hungarian, German, and English languages, and the curators also plan to issue an exhibition catalog in these four languages.
} 
The central connection between the Hungarian, Slovak, and German witnesses of postwar population transfers is put forth in the exhibition's arrangement in the form of houses, mainly Hungarian, Slovak, and German "homes". This idea, based on the universal concept of "home", was brought about by Réka Szabó, who designed the exhibition precisely within the given space (Martin Piaček, e-mail to author, June 8, 2017; Hushegyi 2017). The respective "homes" are symbolized by the displayed material objects of everyday use, such as chairs, mirrors, cupboards, and clothes with embroidery, in particular languages. The exhibited household equipment is authentic, borrowed from several ethnographical museums from South Slovakia (Galanta, Dunajská Streda, and Rimavská Sobota) or from the Museum of Carpathian German Culture. This is what highlights the attempts by the curators to cooperate with more institutions of diverse nationalities in today's Slovakia and promote the idea of a shared culture. Similar to what Williams analyzed in his book Memorial Museums (Williams 2008), the displayed objects of everyday use should bring the visitor closer to the experience of the people, forced to leave their homes, through emotional connotations. The aim of the exhibition is to make visitors feel the emotions of the victims (Williams 2008, 108) using not just static objects but also an interactive dimension such as, e.g., revolving cupboards with salt cellars headed by different languages, in their own way representing the desired narrative of how quickly the homes during the postwar period changed from German or Hungarian to Slovak and the other way around (Hushegyi 2017).

Another important component of the exhibition is the individual testimonies presented in the form of oral history interviews and complemented by archival documents, such as transportation cards for evacuees, orders of the National Security Corps ${ }^{12}$ documents issued by labor camps, etc. The testimonies in the Hungarian, Slovak, and German languages include negative, as well as some positive, experiences of the victims, which again transmit the message of shared pasts and fates. To show the differences between the personal experiences and the official postwar narrative of the population transfers, the curators decided to include excerpts from television news as well (from both Slovak and Hungarian film archives). This idea to confront the state propaganda and the testimonies of people who went through the events proves the courage of the curators to touch a very sensitive topic, but, on the other hand, it leaves visitors the chance to make their own opinion, something I consider to be a wise approach in the context of the "once-taboo" topic. The effort for reconciliation between the minorities and the majority

12 In Slovak: Zbor národnej bezpečnosti, ZNB. 
society is visible in the choice of exhibited testimonies, containing all possible experiences, as well as through the simultaneous cooperation of various actors in the exhibition, some who lent the objects on display but also those financially supporting the exhibition. ${ }^{13}$

Exchanged Homes is an extraordinary exhibition in terms of coping with traumatic and controversial pasts of Slovak history. The curators, with the help of historians, have provided a balanced picture of postwar events, not just from the point of view of the Hungarian and German minorities, but also with respect to the people of Slovak nationality. Therefore, it is a shame that this exhibition is somewhat hidden from the public space, potentially due to its placement in the Museum of Hungarian Culture (whose curators are the authors of the exhibition), which attracts only a minor segment of the society, as well as its lack of easy accessibility. This might be one of the reasons for the lower attendance of visitors relative to the curators expected (Hushegyi 2017). ${ }^{14}$ Another reason can be the lasting sensitivity of the topic or the fact that the exhibition receives far less advertisement. It is striking that the publicity for the exhibition is disseminated mainly in Hungarian- or German-speaking online media (Lakatos 2016; karpatenblatt.sk 2017), whereas the majority of the Slovak online press did not report on the exhibition despite press releases from the curators (Hushegyi 2017). For these reasons, it is questionable how the efforts of the exhibition aimed at overcoming the tragic pasts of Slovak history can succeed.

On the other hand, as discussed earlier, the number of exhibitions displaying the traumatic and controversial events of the 20th century is growing, even though the topics of resettlement and exclusion of the Hungarian and German minorities are less visible. ${ }^{15}$ In addition to the exhibition Exchanged Homes,

13 The exhibition was financially supported by the Government Office of the Slovak Republic, Hungarian Ministry of Human Capacities, and the citizens association Traditions and Values (Tradicie a hodnoty).

14 In the interview, János Hushegyi showed slight disappointment with the lower number of visitors and stated that the final numbers will be available in 2018 after the end of the exhibition (Hushegyi 2017). Another problem with the counting of the visitors is that the exhibition is a part of the whole permanent exhibition of both the Museum of Hungarian Culture in Slovakia and the Museum of Carpathian German Culture, which are situated in one building.

15 Right before submitting this paper, the author came across a newly opened (11/2017) art exhibition in Šmorín (later in 12/2017 exhibited in the Hungarian Institute in Bratislava), described in Hungarian as an exhibition "On the Occasion of the 70th Anniversary of the Expulsions from Slovakia (Felvidék) la felvidéki kitelepitések 70. évfordulója alkalmábóll" (in Slovak: "In Memory of Moved Out and Dragged Off“ Ina pamiatku vystahovaných a odvlečených/). This exhibition, organized by the Society for Common Goals (Spoločnost'za spoločné ciele - Szövetség a Közös Célokért) and the Hungarian Gallery in Bratislava, presented art works connected to the population exchange between Czechoslovakia and Hungary. See: http://samorin.sk/hu/kitelepitesek-emlekkiallitas-holnaptol-a-vmk-ban/ and https://www.facebook.com/kitelepitesek70/. 
it is worthwhile to mention a common project of the Austrian Academy of Sciences and the Czech and Slovak citizens associations Antikomplex and Antikomplex.sk, named Bringing Together Divided Memory. This project focused on the experiences during the period between 1938 and 1947 from the viewpoint of German, Czech, and Slovak speakers in terms of the possibility of creating a common narrative ("Bringing Together Divided Memory," n.d.). The outcome of this project was exhibited during the first half of 2016 in Vienna, Prague, and Bratislava in the form of biographical video interviews, and the recorded testimonies were also published online. ${ }^{16}$

The exhibition Divided Memories (Rozdelené spomienky) in Bratislava took place in the University Library and, because of its popularity among visitors, was even prolonged ("Univerzitná knižnica - Skončila sa nevšedná výstava 'Rozdelené spomienky," n.d.). Interestingly, the exhibition was moved a month later to important cities for the German minority in Slovakia-Kežmarok and Handlová; currently, the Museum of Carpathian German Culture, part of the SNM, plans to renew its permanent exhibition by including the Divided Memories exhibition. There are a couple of reasons why this project and connected exhibitions have gained popularity while also having a broader impact. Compared to Exchanged Homes, Divided Memories was significantly more present in the public sphere because of its international range (and its cooperation with the Austrian Academy of Sciences ${ }^{17}$ ). The placement of the exhibition in the University Library could have also attracted a broader range of visitors than Exchanged Homes, situated in the Museum of Hungarian Culture in Slovakia. However, the main aim of these exhibitions was not to compete for popularity but to further encourage a society wide discussion about the troubled pasts of the German and Hungarian minorities in Slovakia.

\section{Conclusion}

My aim in this paper was to analyze how official Slovak institutions of remembrance deal with the controversial postwar events with respect to the Hungarian and German minorities. In order to find out if and how the state narrative of forced resettlements presented in cultural institutions changed since the fall of the communist regime, my case selection was limited to official museums and art galleries. As the case study of the exhibition Exchanged Homes has shown, the discussion about the painful pasts of Hungarians and

\footnotetext{
16 “Ikt Oeaw." 2017. YouTube. https://www.youtube.com/channel/UC2vk8_FpOn2WedKq0owhNTA.

17 One of the outcomes of the project was also a publication. See: Traska, Georg, ed. Geteilte Erinnerungen / Rozdělené Vzpominky / Rozdelené Spomienky. Wien: Mandelbaum Verlag, 2017.
} 
Germans slowly found its way into the most important Slovak museumssuch as the SNM, even though only in its smaller branch. The Hungarian and German minorities are no longer considered "nation's betrayers", and contemporary exhibitions in museums try to challenge the simplified narrative of the postwar events. Still, if the exhibition Exchanged Homes, concerned with the common traumatic fates of Slovaks, Hungarians, and Germans, is to contribute to the improvement of relations between the majority society and minorities, substantial reactions would be needed (Brown 2013, 280). In conclusion, the curators of the exhibition made a great effort to sensitively treat the painful topic, and we will see what the final evaluation of the exhibition will be after it ends in December 2018. In the context of plans for the new permanent exhibition of the Museum of Hungarian Culture in Slovakia and maybe even of the renovated Museum of History, the curators could include the parts of the contemporary exhibition Exchanged Homes and continue in presenting difficult pasts of Slovakia through various perspectives.

\section{References}

"Ako sme žili? Slovensko v 20. storočí [How We Lived? Slovakia in the 20th Century]." 2008. Accessed June 6, 2017. http://www.panorama.sk/go/clanky/1430.asp?lang=sk.

“Ausstellung 'Der Austausch Der Heimat' [Exhibition 'Exchanged Homes'].” 2017. Accessed January 22, 2018. http://www.karpatenblatt.sk/ausstellung-der-austausch-der-heimat/.

Assmann, Aleida. 2011. "From 'Canon and Archive.”' In The Collective Memory Reader, edited by Jeffrey K. Olick, Vered Vinitzky-Seroussi and Daniel Levy, 334-37. Oxford: Oxford University Press.

Autry, Robyn. 2013. "The Political Economy of Memory: The Challenges of Representing National Conflict at 'Identity-Driven' Museums.” Theory and Society 42 (1): 57-80.

Barnovský, Michal. 2004. "Sovietsky zväz, komunisti a riešienie mad’arskej otázky na Slovensku v rokoch 1945-1950 [The Soviet Union, the Communists and the Solution of the Hungarian Question in Slovakia in the Years 1945-1950].” In Bolševismus, komunismus a radikálni socialismus v Československu: Svazek III [Bolshevism, Communism, and Radical Socialism in Czechoslovakia: Volume III], edited by Zdeněk Kárník and Michal Kopeček, 154-82. Praha: Dokořán.

Blažej, Ján. 2002. "Stred Európy okolo roku 1000 [Centre of Europe around the Year 1000].” Accessed June 6, 2017. http://dennik.hnonline.sk/servisne-prilohy/31796-stred-europyokolo-roku-1000.

Bobák, Ján. 1982. “Výmena obyvatel'stva medzi Československom a Mad’arskom (1946-1948) [Population Exchange between Czechoslovakia and Hungary (1946-1948)]." In Slováci v zahraniči [Slovaks Abroad] 8, edited by František Bielik and Claude Balázs. Martin: Matica slovenská.

"Bringing Together Divided Memory." n.d. Austrian Academy of Sciences. Accessed June 13, 2017. https://www.oeaw.ac.at/en/ikt/research/sites-of-memory-spaces-of-memory/bringing-together-divided-memory/. 


\section{Tereza Juhászová, The Troubled Pasts of Hungarian and German Minorities in Slovakia and Their Representation in Museums}

Brown, Kris. 2013. "Commemoration as Symbolic Reparation: New Narratives or Spaces of Conflict?" Human Rights Review 14 (3): 273-89.

“Dream $\times$ Reality | Art \& Propaganda 1939-1945.” 2016. Slovak National Gallery. Accessed June 9, 2017. http://www.sng.sk/en/exhibitions/728_dream-utf215-reality-art-propaganda-1939-1945.

Esbenshade, Richard S. 1995. "Remembering to Forget: Memory, History, National Identity in Postwar East-Central Europe." Representations, 49: 72-96.

Gabzdilová-Olejníková, Soňa, Milan Olejník and Štefan Šutaj. 2005. Nemci a Mad'ari na Slovensku v rokoch 1945-1953v dokumentoch [Germans and Hungarians in Slovakia in the Years 1945-1953 in Documents]. Prešov: Universum.

Gabzdilová-Olejníková, Soňa, and Milan Olejník. 2004. Karpatski Nemci na Slovensku od druhej svetovej vojny do roku 1953 [Carpathian Germans in Slovakia since World War II until 1953]. Bratislava: Společenskovedný ústav SAV, Múzeum kultúry karpatských Nemcov.

Gyárfášová, Ol'ga. 2012. "Is This Exhibition Really Critical?” Institute for Public Affairs. Accessed January 22, 2018. https://institutpre.blog.sme.sk/c/306540/Is-this-exhibitionreally-critical.html.

"Historické múzeum: História múzea [Historical Museum: History of the Museum]." 2009. Slovak National Museum. Accessed June 8, 2017. http://www.snm.sk/?historicke-muzeum-historia-muzea.

Hudek, Adam. 2011. "National Museums in Slovakia: Nation Building Strategies in a Frequently Changing Environment." In Building National Museums in Europe 1750-2010: Conference Proceedings from EuNaMus, European National Museums: Identity Politics, the Uses of the Past and the European Citizen, Bologna 28-30 April, 2011, edited by Peter Aronsson and Gabriella Elgenius, 817-46. Linköping: Linköping University Electronic Press.

Hushegyi, János. 2017. Interview by Tereza Auzká.

Kacsinecz, Krisztián. 2014. "Prvá svetová vojna - Tragédia, ktorá postihla všetkých [World War I: The Tragedy That Hit Everyone]." Slovak National Museum. Accessed January 22, 2018. http://www.bratislavskerozky.sk/sk/Cerstve-rozky/Velka-vojna/Prva-svetova-vojnatragedia-ktora-postihla-vsetkych-Aktualna-vystava-na-Bratislavskom-hrade-.html.

Koklesová, Bohunka. 2017. "Slovenský štát prilákal do SNG štvornásobne viac ludí ako iné výstavy [The Slovak State attracted four times more people to SNG than other exhibitions]." Slovak National Gallery. Accessed June 13, 2017. https://dennikn.sk/719738/slovensky-stat-prilakal-do-sng-stvornasobne-viac-ludi-ako-ine-vystavy/.

Kusá, Alexandra. 2012. "Slovo kurátorky k výstave Prerušená pieseň [The word of the curator to the exhibition Interrupted song]." Jazdec 4 (4): 1, 3-5.

Lakatos, Krisztina. 2016. "Felcserélt Otthonok a Brämer-Kúriában.” Slovak National Museum. Accessed June 13, 2017. http://ujszo.com/online/kultura/2016/12/04/felcserelt-otthonok-a-bramer-kuriaban.

Manchin, Anna. 2015. "Staging Traumatic Memory: Competing Narratives of State Violence in Post-Communist Hungarian Museums." East European Jewish Affairs 45 (2-3): 236-51.

Maráky, Peter. 2008. "Starý svet nie sú iba vitríny [The Old World is not just Showcases]." Accessed June 13, 2017. https://www.sme.sk/c/3950815/stary-svet-nie-su-iba-vitriny.html. 
2015. "Výstavné sezóny 2014-2015 v slovenských múzeách a galériách [Exhibition Seasons 2014-2015 in Slovak Museums and Galleries].” Muzeológia a kultúrne dedičstvo 3 (2): 97-105.

———. 2017. "Výstavná sezóna v slovenských múzeách v roku 2016 [Exhibition Season in Slovak Museums in 2016].” Muzeológia a kultúrne dedičstvo 5 (1): 174-81.

Mesežnikov, Grigorij. 2012. “Dobrý Stalin?” Institute for Public Affairs. Accessed January 22, 2018. https://institutpre.blog.sme.sk/c/304364/Dobry-Stalin.html.

Nora, Pierre. 1989. “Between Memory and History: Les Lieux de Mémoire.” Representations 26 (Spring): 7-24.

Peters, Florian. 2016. "Towards a Balanced Tribute to the Polish Righteous? The Ulma Family Museum of Poles Saving Jews in Markowa." Cultures of History Forum. Accessed January 22, 2018. http://www.cultures-of-history.uni-jena.de/exhibitions/poland/towards-a-balanced-tribute-to-the-polish-righteous-the-ulma-family-museum-of-poles-saving-jews-inmarkowa/.

Popély, Árpád. 2009. "Plány na vysídlenie mad’arského obyvatel'stva v rámci výmeny obyvatel'stva medzi Československom a Mad'arskom [Plans for the Displacement of the Hungarian Population as Part of the Population Exchange between Czechoslovakia and Hungary].” FÓRUM Spoločenskovedná Revue, 47-66.

Radonić, Ljiljana. 2014. "Das Holocaust-Gedenkzentrum in Budapest - Ein 'unmögliches' Museum? [The Holocaust Memorial Center in Budapest - An 'impossible' museum?].” $M E D A O N$ 15. http://www.medaon.de/pdf/MEDAON_15_Radonic.pdf.

Rivera-Orraca, Lorena. 2009. "Are Museums Sites of Memory?” The New School Psychology Bulletin 6 (2): 32-37.

Sáposová, Zlatica, and Štefan Šutaj, eds. 2010. Povojnové migrácie a výmena obyvatelstva medzi Československom a Mad'arskom [Postwar Migrations and Population Exchange between Czechoslovakia and Hungary]. Prešov: Universum.

Simon, Roger I. 2012. "Museums, Civic Life, and the Educative Force of Remembrance." In Museum Studies: An Anthology of Contexts, edited by Bettina Messias Carbonell, 92-96. Chichester: Wiley-Blackwell.

Siposová, Sylvia. 2017. "Vymenené domovy - Felcserélt otthonok - Austausch der Heimat [Exchanged Homes].” Pamiatky a Múzeá 66 (1): 62-63.

“Slovak Myth.” 2005. Slovak National Gallery. Accessed June 9, 2017. http://www.sng.sk/en/ exhibitions/422_slovak-myth.

Šutaj, Štefan. 2012. Mad’arská menšina na Slovensku v 20. storoči [Hungarian minority in Slovakia in the 20th century]. Bratislava: Kalligram.

"The Berlin (Potsdam) Conference, July 17-August 2, 1945 (a) Protocol of the Proceedings, August L, 1945.” 2008. Lillian Goldman Law Library. Accessed June 12, 2017. http://avalon.law.yale.edu/20th_century/decade17.asp.

“Univerzitná knižnica - skončila sa nevšedná výstava 'Rozdelené spomienky' [University Library - Unusual Exhibition 'Divided Memories' Ended].” n.d. University Library in Bratislava. Accessed June 13, 2017. https://www.ulib.sk/sk/spravy/archiv/skoncila-nevsedna-vystava-rozdelene-spomienky.html. 


\section{Tereza Juhászová, The Troubled Pasts of Hungarian and German Minorities in Slovakia and Their Representation in Museums}

Vadkerty, Katalin, László Szarka, Zoltán Fábry, Rezső Peéry, Rezső Szalatnai and Katarína Borbášová. 2002. Mad’arská otázka v Československu, 1945-1948: trilógia o dejinách mad'arkej menšiny [Hungarian Question in Czechoslovakia, 1945-1948: Trilogy about the History of the Hungarian Minority]. Bratislava: Kalligram.

"Vymenené Domovy - Felcserélt Otthonok." n.d. Slovak National Museum. Accessed May 31, 2017. http://www.snm.sk/?muzeum-kultury-madarov-na-slovensku-aktualnevystavy\&clanok=vymenene-domovy-felcserelt-otthonok.

Williams, Paul. 2008. Memorial Museums: The Global Rush to Commemorate Atrocities. London: Bloomsbury Academic. 